\title{
EFFECT OF ARCHITECTURAL FORM OF GREENHOUSE SOLAR DRYER SYSTEM ON DRYING OF ONION FLAKES
}

\author{
KASSEM, A. M., Y. A. HABIB, S. K. HARB AND K.S.KALLIL \\ Agricultural Engineering Research Institute, ARC, Dokki Giza
}

(Manuscript received 19 September 2010 )

\begin{abstract}
The main goal of the present study was to evaluate the effects of three different architectural forms on drying rate of Onion flakes. These different forms are, gable-even-span $\left(\mathrm{SD}_{1}\right)$, four sidespyramid shape $\left(\mathrm{SD}_{2}\right)$ and hemispherical shape $\left(\mathrm{SD}_{3}\right)$, which are used for drying Onion. Deterioration of considerable quantities of Onion takes place during storage operation. Various preservation methods have been employed to minimize this loss. Solar dryers were designed and constructed at Agricultural Engineering Research Institute. Air was pushed naturally through the holes under the greenhouse solar dryer passing through the agricultural products to carry out the moisture and moving it through the chimney which is installed at the top of the greenhouse solar dryer. There are two experimental operations; the first one was without using rocks (1) the second one with rocks (2) to raise the drying efficiency. The period of dring without rocks takes 45 hours but it takes 42 hours by rockes. The resulting efficiency is $68 \%, 72 \%$ for the $\left(\mathrm{SD}_{1}\right), 62 \%, 69 \%$ for $(\mathrm{SD} 2)$ and $57 \%, 68 \%$ for $\left(\mathrm{SD}_{3}\right)$ for all dryers without rock and with rock respectively. The maximum moisture content removed from $81.2 \%$ to $12.05 \%$, from $81 \%$ to $12.09 \%$ and from $81.2 \%$ to $14.7 \%$ without rock but it was removed from $80.02 \%$ to $8.67 \%$, from $78.33 \%$ to $10.14 \%$ and from $78.59 \%$ to $13.55 \%$ with rock for the three solar dryer $\left(\mathrm{SD}_{1}\right)$, $\left(\mathrm{SD}_{2}\right)$ and $\left(\mathrm{SD}_{3}\right)$ respectively. The total incident solar energy are $39.75,36.96$ and $32.62 \mathrm{~kW}$ for the three solar dryers without rock, respectively, while the three solar dryer with rock gave 46.06, 41.41 and $40.50 \mathrm{~kW}$, respectively. In isolated communities, solar energy is quite often the only heat source which can be used to dry low cost agricultural products economically.
\end{abstract}

\section{INTRODUCTION}

Onion is considered as one of the most important crops in all countries. In Egypt, the total cultivated onions area is about 123.352 feddan with a productivity of 11.92 tons/feddan (Medwest Universities Consortium for International Activities (MUCIA) DATABASE, 2004). Egypt exports about 302.412, 19.096 and 12.170 tons of fresh, dry and green onion respectively (Marketing Technology Information Network-UPEHC (2006) Magdi A., A. Mousa and Mohamed F. Mohamed (2009). Innovation of renewable energy technique is very important to replace traditional energy sources as an alternative to commercial fuels such as fire wood, coal, oil and electricity. People 
have drying plants for thousands of years by placing the plants on mats in the sun. This simple method, however, allows the plants to be contaminated by dust, airborne, molds and fungi, insects, rodents and other animals. Furthermore, open air drying is often not possible in humid climates. Drying is a simple low cost method to preserve and to prevent fermentation or the growth of molds. Greenhouse solar plants dryers represent a major improvement upon this ancient method. Although greenhouse solar dryers involve an initial high cost, they produce better looking, better tast and more nutritious plant, enhancing both their plants value and their marketability. They also are faster, safer and more efficient than traditional sun drying techniques.

Greenhouse Solar dryers use the energy of the sun to heat the air that flows through the plants in the dryer. As air is heated, its relative humidity decreases and it is able to remove more moisture. Warm dry air flowing through the dryer carries away the moisture that evaporates from the plants.

Solar drying is one of the oldest techniques employed in agriculture and solar crop dryers have been built by the solar energy projects all over the world. Dryers have varied in size from the $2.2 \mathrm{~m}^{2}$ wire basket dryer to the $149 \mathrm{~m}^{2}$ roof collector. Most solar dryers use solar air heaters and the heated air is then passed through the crop. The smaller solar dryers use natural convection or chimneys for air circulation, but for solar collectors of more than $10 \mathrm{~m}^{2}$, forced convection is usually necessary. Dryers which use an existing building are economically very attractive. Hollick (1998) has described a dryer in India for drying 30 tones per day of sesame seeds, chilly and coriander using a collector of $1120 \mathrm{~m}^{2}$ attached to an existing fossil fueled dryer to replace about $40 \%$ of the conventional fuel with solar energy. He calculates a payback time of 2.1 years. EL-Sahrigi,A.F. et al.,(1999) stated that structural frame of gableeven-span form had some advantages over the modified Quonset form particularly at night during winter season and at daylight during summer season. During winter season, the gable-even-span form reduced the loss of heat from the greenhouse between $5.15 \%$ and $8.59 \%$ compared with the modified quonset form, due to influences of curvature surface area on the heat transfer area. During summer, the modified quonset form increased the solar radiation available inside the greenhouse by $13.16 \%$ compared with the gable-even-span form because of roof curvature. Consequently, the structural frame of gable-even-span form increased the cucumber fresh yield by $14.64 \%$ and $14.73 \%$ respectively. The conditioned greenhouses enhanced the rate of vegetative growth, and on the average increasing the cucumber fresh yield by $84.04 \%$ and $140.75 \%$ for winter and summer crops respectively compare with the unconditioned greenhouses. 
There is no doubt that the most readily applicable solar technology in helping farmers or fishermen in reducing post harvest losses, is by means of the solar drying system. There are many researchers in the past proposing several designs of solar dryer, with the aims to apply the system under rural conditions. Mühlbauer,W, Esper, A. and Müller,J. (1993), for example had developed a tunnel dryer which is quite popular in Asia (Bala and Mondol, 1999) and Africa (El-Shiaty, M., A. Müller, Mühlbauer W, 1991.) due to its relatively low cost and can be easily being operated by local farmers or fishermen. Sattar (1990) proposed a solar drying system to dry timber for use in Bangladesh, while Garg (1990) made a review on the prospects of various designs of solar crop dryers. Basically, solar dryers can be divided into two categories although some deviations from these basic configurations that can be found in the literature. The first category belongs to those systems in which a solar heat collector is used to supply hot air to a drying chamber, while the second category refers to those where hot air is generated within the drying chamber by using the green house effect. Ranjita Bezbaruah Sharma (2009)stated that, it has been found that solar dried products for example bananas and tapiocas were sweeter than the raw one. Solar dryers are very useable and it will help the community to have nutritious processed foods to be eaten for long periods. El-Kholy (2003) cited that the solar dryer used solar heated air passing by natural convection bed. The results showed that, drying started simultaneously at the top and bottom of the bed, while the middle layer dried slowest. Periodic stirring of the bed of paddy reduced the drying time by about 4 hours and led to a uniform grain moisture content at different layers of the drying bed .Sherif M. Radwan (2002) said that the greenhouse typesolar dryer was able to dry grapes treated sample with alkaline-sulfuring per treatment in 36 hours comparing with 54 hours for sun drying method. The corresponding times for pre-treated sample with ethyl stearate were 42 and 58 hours respectively. Quality evaluation tests of the dried raisins showed that, Vitamin C content was the only chemical component significantly decreased, the reduction rate was higher for sun drying method compared with solar drying method. On the other hand, an improvement in rehydration ratio and raisins color was observed for solar drying method compared with sun drying method and for ethyl stearate sulfuring per treatment samples compared with alkaline-sulfuring pretreatment. Abu-Habaga, et al., (2010) said that the use of the greenhouse type solar dryer with chopping and crushing of the green tops could decrease the drying time of sugar beet tops by about 47 to $59 \mathrm{~h}$ in comparison with the traditional drying method which has taken about 78 hours. The thermal efficiency of the dryer ranged from 34.12 to $22.96 \%$ and the protein content of the dried tops ranged from 12.57 to $14.52 \%$ on DM basis. 
The main objective of the present research work was to study, test and evaluate some of the most important engineering parameters which affecting the working performance of the greenhouses in drying Onion crops. These parameters included three different architectural forms of greenhouses and the effect of rocks as heat storage materials in the thermal performance of this type of dryers. To achieve this, two different experiments were carried out in three plastic greenhouses solar dryer, one of them without rocks and the second with rocks.

\section{MATERIALS AND METHODS}

Three greenhouse solar dryers were designed, built and installed on a concrete floor of the roof of the Agricultural Engineering Research institute. The gross surface area of them is $1.77 \mathrm{~m}^{2}$. The first greenhouse was gable-even-span shape $\left(\mathrm{SD}_{1}\right)$ is shown in Figure (1) which was established on a wooden base of gross dimensions are $1.77 \mathrm{~m}$ long and one $\mathrm{m}$ width $0.29 \mathrm{~cm}$ height and it's side wall orientated and inclined with one tilt angle equal the latitude angle of the place $\left(30^{\circ} \mathrm{N}\right)$, the second one is Pyramidal greenhouse solar dryer shape $\left(\mathrm{SD}_{2}\right)$ Figure (2) with square surface area was established on a wooden base of gross dimension of $1.3 \mathrm{~m}$ side length and it's side wall orientated and inclined with a tilt angle equal the latitude angle of the place $\left(30^{\circ} \mathrm{N}\right)$. The third one is of half spherical shape $\left(\mathrm{SD}_{3}\right)$ as shown in Figure (3) dome greenhouse dryer was established on a wooden base having gross diameter of 1.50 $\mathrm{m}$. All greenhouse solar dryers base had three square holes of gross dimensions side length $5 \times 5 \mathrm{~cm}$ located at the bottom of the wooden base to allow the air pushed from under the dryer to its top passing through the agricultural products, its bases also covered by perforated metal network.

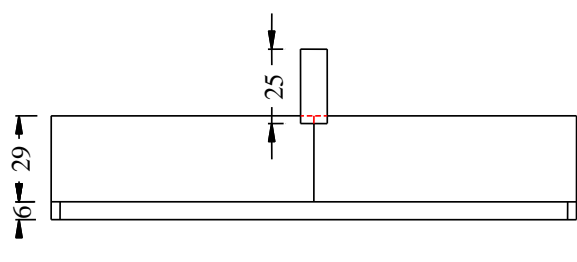

Elevation

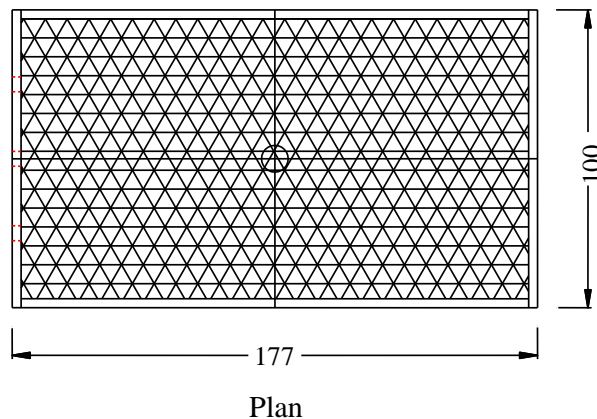

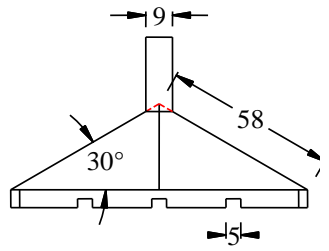

Side view

Figure 1. The gable-even-span shape greenhouse solar dryer 
The frame of the greenhouse solar dryers which were made of iron wire of one $\mathrm{cm}$ diameter, covered with transparent plastic sheet. Every dryer had a chimney and the top of $10 \mathrm{~cm}$ diameter to remove the humid air outside after being used in the dryer. Solar dryer were oriented to the north-south direction.

The meteorological data from a meteorological station (The meteorological data station, sixteen channels [Consort nv T851, Resolution $<1000{ }^{\circ} \mathrm{C}$, : $0.1{ }^{\circ} \mathrm{C}\left(0.1{ }^{\circ} \mathrm{F}\right)$ Digital output, Programmable RS 232, 1500-4800 b/s, for twin-directional communication of the computer and/or printer] 16 channels which were installed beside the greenhouses solar dryers where 14-thermocouples to measure the dry and wet bulb temperatures inside and outside. Six thermocouples were used to measure the dry bulb temperature, two thermocouples for each greenhouse solar dryers, three thermocouples were used to measure the wet bulb temperature inside the greenhouse solar dryer, three thermocouples were used to measure the humid air temperature going outside the chimney from each greenhouses solar dryer and one thermocouple was used to measure the outside ambient air temperature and one thermocouple to measure the outside wet temperature.
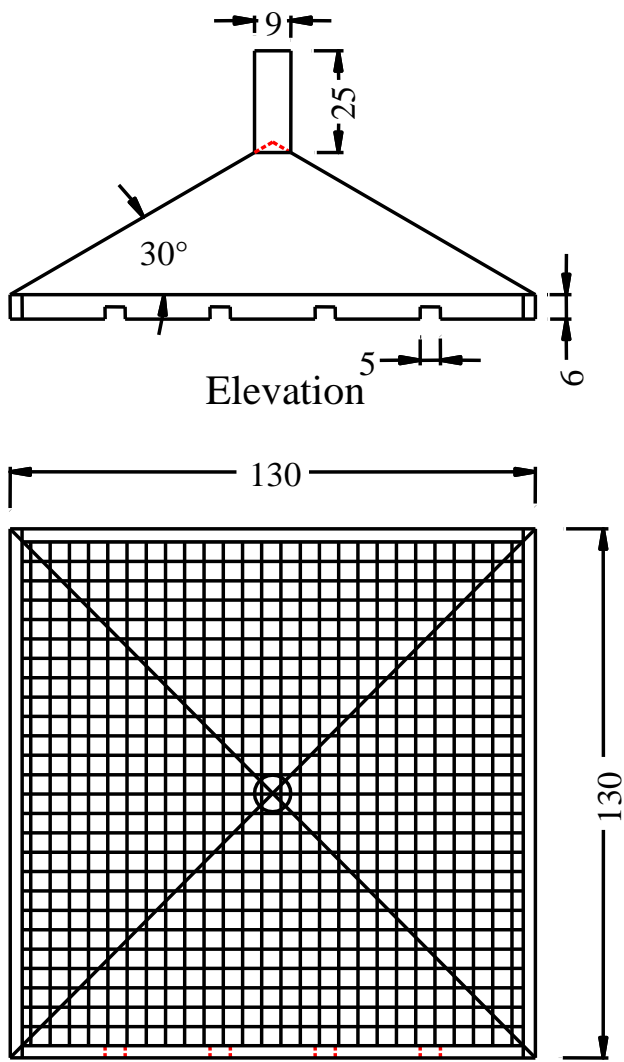

Plan Dim. in cm.

Figure 2.The paramedical greenhouse solar dryer 

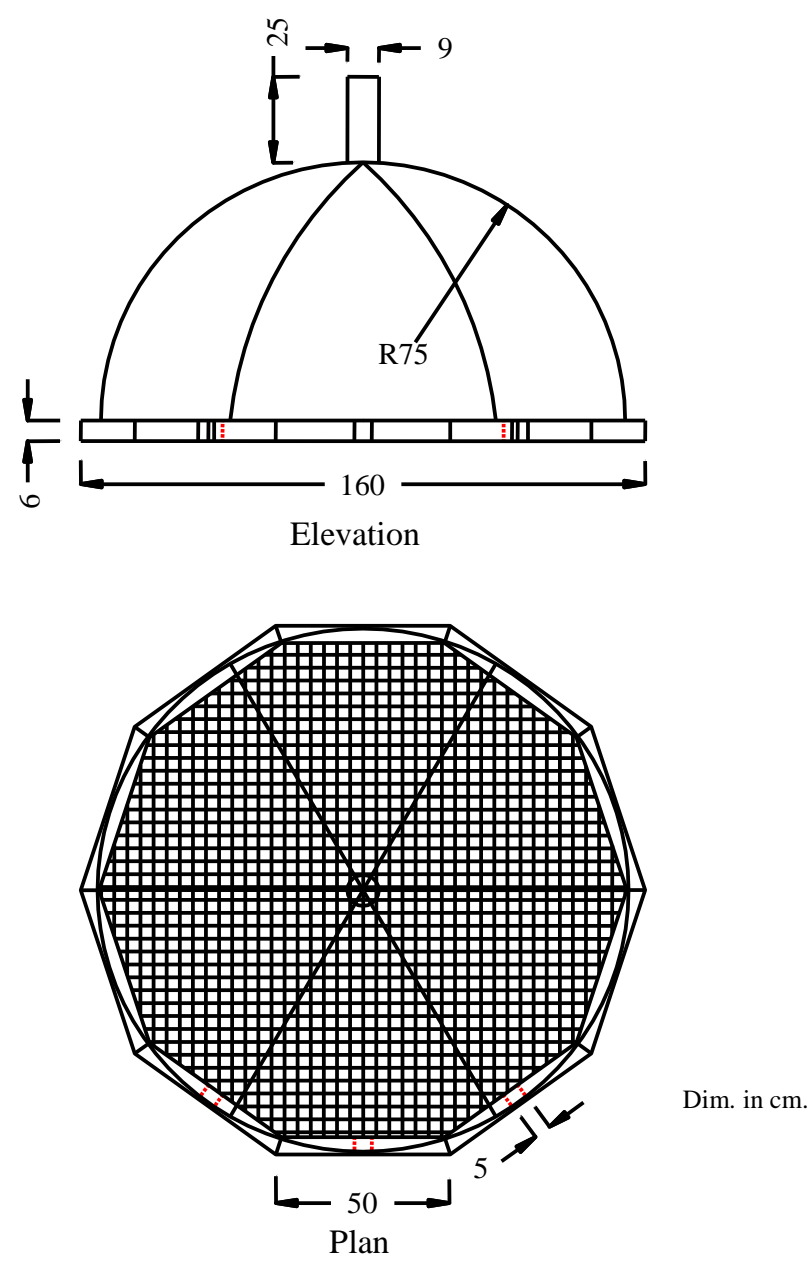

Figure 3. The half spherical shape greenhouse solar dryer

The Four solar meters were fixed and installed on each greenhouse solar dryer and one outside in order to measure the solar radiation flux incident. These sensors were connected to a data logger system to display and record the obtained data throughout the experimental work. The parameters of thermal performance test and the relationship between them are examined and tested by the steady state energy balance was computed using a series of equations (Abdellatif and Lieth, 1992), as the follows:

$\begin{array}{ll}\mathbf{Q}_{\text {load }}-\mathbf{Q}_{\text {Loss }}-\mathbf{Q}_{\text {gain }}=\mathbf{0} & \text {,Watt } \\ \mathbf{Q}_{\text {load }}=\mathbf{Q}_{\text {Loss }}+\mathbf{Q}_{\text {gain }} & , \text { Watt } \\ \mathbf{Q}_{c}=\mathbf{U}_{\mathbf{o}} \mathbf{A}\left(\mathbf{T}_{\mathrm{ai}}-\mathbf{T}_{\mathrm{ao}}\right) & , \text { Watt } \\ \mathbf{Q}_{\text {inf }}=\mathbf{m}_{\mathbf{a}} \mathbf{C p}\left(\mathbf{T}_{\mathrm{ai}}-\mathbf{T}_{\mathrm{ao}}\right) & , \text { Watt }\end{array}$




\section{Where:-}

$\mathbf{Q}_{\text {gain }}=$ Solar heat gain

$\mathbf{Q}_{\text {Loss }}=$ Heat losses

$\mathbf{Q}_{\text {load }}=$ Heat load

$\mathbf{Q}_{\mathbf{c}} \quad=$ Combination heat losses or gain (by conduction, convection and radiation) through

the concrete blocks and glass cover of the glasshouse.

$\mathbf{Q}_{\text {inf }}=$ Heat losses due to cold air infiltration (through the structure) from outside to inside

of the greenhouse.

$\mathbf{U}_{\mathbf{0}} \quad=$ Overall heat transfer coefficient.

A $\quad=$ Wall surface area.

Cp = Specific heat of air.

$\mathbf{m}_{\mathbf{a}} \quad=$ Mass flow rate of air.

$\mathbf{T}_{\mathbf{a}} \quad=$ Inside ambient temperature.

$\mathbf{T}_{\mathrm{ao}} \quad=$ Outside ambient temperature.

The solar heat gain can be estimated by the following equation (ASHRAE, 1983) :-

$\mathbf{Q}_{\text {gain }}=L_{s} A_{f} \lambda$

$\mathrm{L}_{\mathrm{s}} \quad=$ Solar radiation flux incident, $\mathrm{W} / \mathrm{m}^{2}$

$A_{f} \quad=$ Floor surface area of greenhouse, $\mathrm{m}^{2}$

$\Lambda=$ Effective transmittance of the greenhouse cover, Decimal

The effectiveness of the heat distributing system can be calculated as a function of inside air temperature $\left(T_{a i}\right)$, outside air temperature $\left(T_{a o}\right)$, and set point temperature $\left(T_{\text {op }}\right)$ by the following formula :-

$\eta_{f f}=\frac{T_{a i-} T_{a o}}{T_{o p}-T_{a o}} \times 100 \quad, \%$

$\boldsymbol{\eta}_{\mathrm{ff}}=$ heat distributing system effectiveness, $\%$

Data were measured and stored in microcomputer files and statistically analyzed using excel program. An empirical equation for energy balance on the greenhouse at night time and predicting ambient air temperature inside the greenhouse were developed. All the previous equations were employed and listed in an arithmetic program written in BASIC. One of the most useful applications of computer models of physical problems is simulation. Once a model is tested and found to be accurate, it can be used to predict results which could otherwise be obtained with extensive and costly experimentation. 


\section{RESULTS AND DISCUSSION}

Under clear sky conditions, solar energy available, dried Onion crop under three greenhouse solar dryer have different architectural form having the same base area $1.77 \mathrm{~m}^{2}$ per each. Figure (4) shows the water removal during the two experiments (without rocks $\left(\mathrm{WR}_{1}\right)$ and with rocks $\left(\mathrm{WR}_{2}\right)$ for the three solar dryers $\left(\mathrm{SD}_{1}, \mathrm{SD}_{2}\right.$ and $\mathrm{SD}_{3}$ ). From the figure, it found that the water removals from $60 \mathrm{gm}$ onion sample are $51.1,47.2$ and $42.27 \mathrm{gm}$ at the three solar dryers with rocks respectively. But it was $47.5,46.9$ and $33.5 \mathrm{gm}$ respectively at the drying without rocks. Also it can be seen that the Gable Even Span solar dryer (SD1) have the best result at the two experiments.

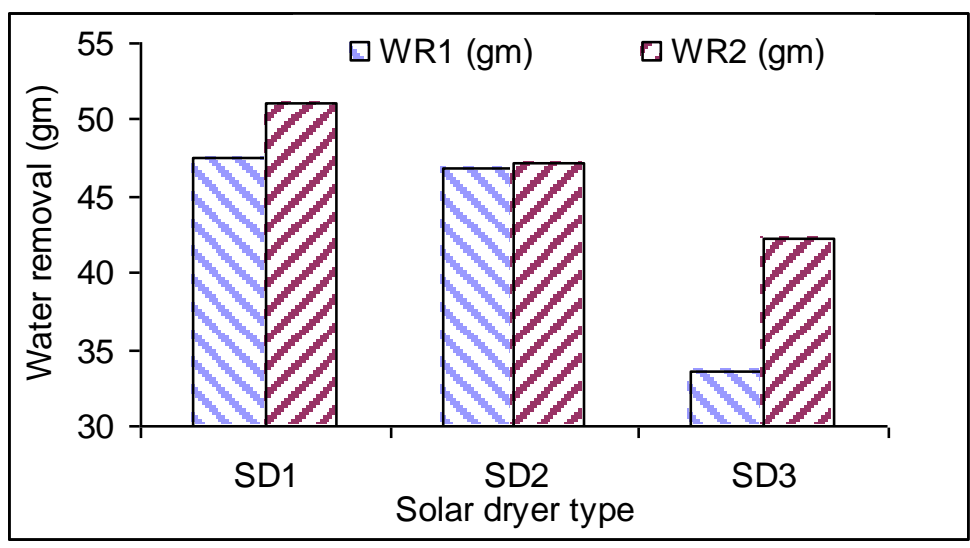

Figure 4. Water removal in the three dryer with rock and without rock during the drying process

Figures (5) and Figure (6) show the total gaine and losses of solar energy during the two experiments. It noticed that the Gable Even Span $\left(\mathrm{SD}_{1}\right)$ solar dryer continuously absorbed a highest solar energy $39.75 \mathrm{kw}$ during the two experiments respectively, but the Hemispherical shape $\left(\mathrm{SD}_{3}\right)$ absorbed less solar energy 32.62 and $40.50 \mathrm{kw}$. 


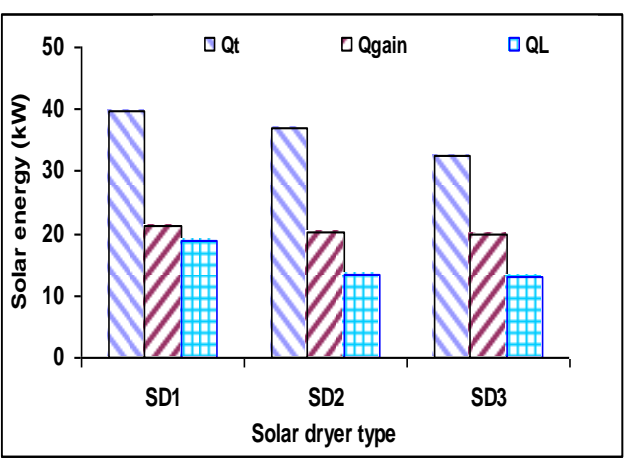

Figure 5. total, gain and losses solar energy during the drying process

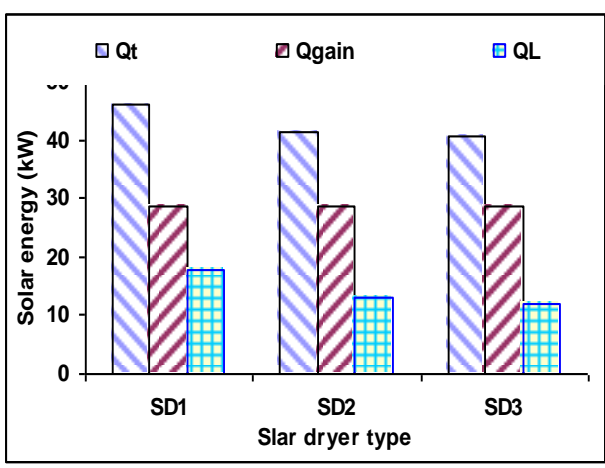

Figure 6. total, gain and losses solar energy for three solar dryer during the drying process

Figure (7) shows the drying process efficiency for the two experimental work for the three different solar dryers $\left(\mathrm{SD}_{1}, \mathrm{SD}_{2}, \mathrm{SD}_{3}\right)$, the mean values for the drying efficiency were $68 \%, 62 \%$ and $57 \%$ respectively for without rocks experiment and $72 \%, 69 \%$ and $68 \%$ respectively for with rock experiment. It clearly reveals that the Gable Even Span solar dryer efficiency increased than the other solar dryers efficiency.

Figure (8) shows the moisture content percentage at the begging of the two experimental work until the end for experiment without rocks were $81.20 \%$ to $2.38 \%$ for the gable even span solar dryer from, but the four sides-pyramid shape solar dryer were $81 \%$ to $3.55 \%$ and the hemispherical shape solar dryer were $81.20 \%$ to $2.94 \%$ and the drying time were fifty one hour. Figure (9) clearly reveals moisture content at the experiment with rocks which were $80.2 \%$ to $2.67 \%$ for $\left(\mathrm{SD}_{1}\right), 78.33 \%$ to $3.14 \%$ for $\left(\mathrm{SD}_{2}\right)$ and $78.59 \%$ to $2.55 \%$ for $\left(\mathrm{SD}_{3}\right)$ respectively and the drying time were forty two hour.

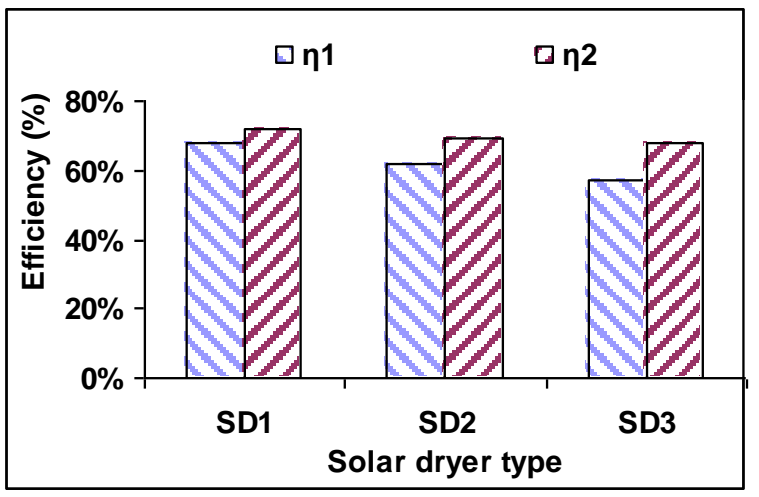

Figure 7. solar dryers' efficiency without rock and with rock during the drying process 

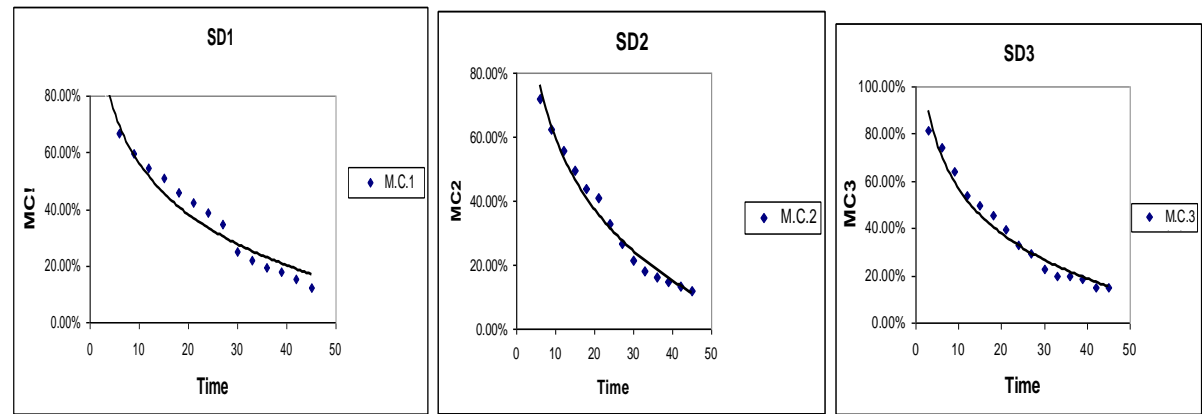

Figure 8. Moisture content percentage the three solar dryers during the drying process without rocks
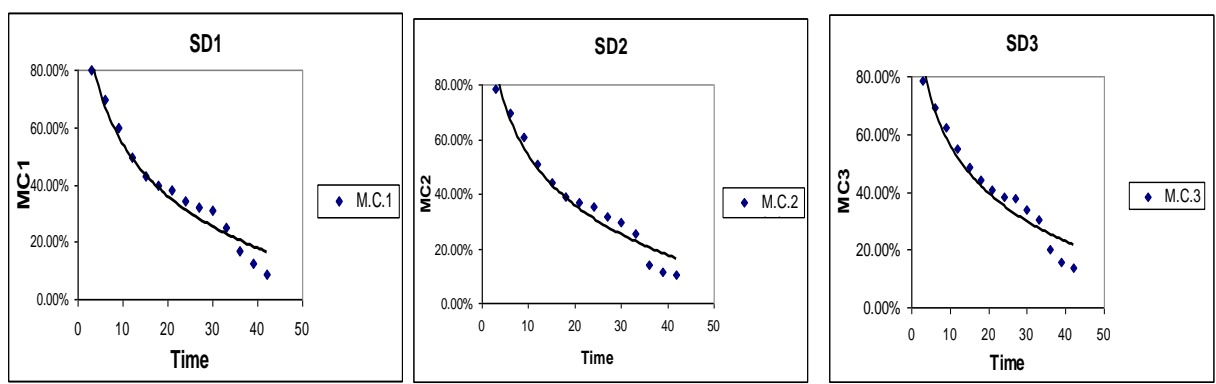

Figure 9. Moisture content percentage for the three solar dryers during the drying process with rocks

\section{CONCLUSION}

From the previous data clearly reveals that the Gable Even Span solar dryer was the most convenient since it gave highest removal of water, less moisture content, high gain solar energy, less solar energy lost and highest efficiency during the two experimental operations :

1- It removes $51.1 \mathrm{gm}$ water from $60 \mathrm{gm}$ Onion sample at $\left(\mathrm{SD}_{1}\right)$ with rocks which was $47.5 \mathrm{gm}$ without rocks.

2- It gains 39.75 and $46.06 \mathrm{~kW}$ during the experimental operations without and with rock respectively.

3 - It has the highest efficiency $68 \%$ and $72 \%$ respectively with rock and without rock. 


\section{REFERENCES}

1. Abdellatif, S. M. and H. J. Lieth. 1992. "Heat requirement for maintaining optimum ambient air temperature of greenhouses" Misr, J. Ag. Eng., Vol. 9(4): 635-655.

2. ASHRAE,1983. Evaporative air-cooling equipment. Chapter 4., In equipment handbook, American Society of Heating Refrigerating Air Conditioning Engineers, Inc.

3. Abu-Habaga,M.E., M.M. El-Koly and R.Z. Emara. 2010. "Utilization of solar energy for drying sugar beet tops" J.Soil Sci and Agric. Engineering, Mansoura Univ., Vol.(7):681-697.

4. Balladin D. A and O. Headley. 1999. Evaluation of solar dried thyme (Thymus vulgaris Linné) herbs. Renewable Energy, 17, 523 - 531.

5. Bala, B.K. and M.R.A. Mondol. 1999. "Experimental investigation on solar drying of fish using solar tunnel dryer, Kamaruddin A., A.H. Tambunan and A.S. Mujumdar, Ed. Proceedings of the 1st Asian-Australian Drying" Conference, Bali, Indonesia, October. ISBN 979-493-068-7.

6. El-Kholy, M.M. 2003. "Development and evaluation of a natural convection solar dryer" J.Agric. Sci. Mansoura Univ.,28(5) : 3967 - 3982.

7. El-Sahrigi, A.F., S.M. Abdellatif, A.M. Matouk, Y.M. El-hadidi and A.M. Kassem. 1999. "Environmental control effectiveness of growing cucumber crop under different structural frame of greenhouses" Misr, J. Ag. Eng., Vol. 16(2): 193-208.

8. El-Shiatry, M., A. Müller, W. Mühlbauer. 1991. Drying fruits and vegetables with solar energy in Egypt. Agricultural Mechnization, in Asia, Africa and Latin America. 22(2);pp.61-64.

9. Garg, H.P. 1990. Status and Prospects of Solar Crop Dryers, A.A.M. Sayig Ed. Energy and the Environment-into the 1990s., Vol.2, Pergamon Press.

10. Hollick J. C. 1998. Commercial scale solar drying. Renewable Energy, Vol. 16, pp 714 - 719.

11. Magdi A.A. Mousa and Mohamed F. Mohamed. 2009. "ENHANCED YIELD AND QUALITY OF ONION (ALLIUM CEPA L. CV GIZA 6) PRODUCED USING ORGANIC FERTILIZATION" Assiut. Univ. Bull. Environ. Res. Vol. 12 No. 1, March 20.

12. Mühlbauer, W., A. Esper and J. Müller. 1993. Solar Energy in Agriculture, ISES, Solar World Congress, Budapest, August 23-27.

13. Ranjita Bezbaruah Sharma. 2009. "Thematic studies for processing and preservation of food supplement, chilies and ginger by drying through solar energy" International Solar Food Processing Conference 2009.

14. Sattar, M.A. 1990. Rural Application of Solar Energy-Timber Drying. A.A.M. Sayig Ed. Energy and the Environment-into the 1990s., Vol.2, Pergamon Press.

15. Sherif M. Radwan. 2002. "Utilization of solar energy for drying grapes under Egyptian climatic conditions" Misr J.Ag.Eng.,19(1) : 100-112. 


\section{تأثير الثكل الهندسي لنظم صوب التجفيف الثمسية على تجفيف شرائح البصل}

أحمد محمد قاسم ، يسرى أحمد حبيب ،مير قرني حرب ، خليل سبد خليل

$$
\text { بععه بحوث الهندسة الزراعة - مركز البحوث الزراعية- دقي - جيزة }
$$

هذا البحث يصف تصميم و تشغيل ثلاث مجفقات شمسية لها أثكال مختلفة أحداهما جملوني

الثكل (SD1) ، و الثاني هرمي رباعي الثكل (SD2) و الثالث نصف كروي الثكل (SD3) . و

جميعهم يِيتخدم في تجفيف محصول البصل. المجفقات الثمسية تم تصميمها وبناؤها في معهد بحوث الهندسة الزر اعية. جميع المجفقات الثنمسية مصنوعة من قاعدة خشبية ذات مساحة سطحية و احدة 1.77 م2 و كل مجفف مزود نبلاث فتحات مربعة الثنكل (5 × 5 سم) لسهولة حركة الهواء داخل المجف الثمسي ، و الإطار المصنوع من الحديد قطره 1 سم ، و تم تغطية المجفات بغلاف من البلاستيك سمك 200 ميكرون. يدفع الهو اء الساخن من خلال التقوب ليمر خلال المنتج (البصل) لانتزاع الرطوبة و التخلص منه عن طريق تحريكه عبر المدخنة التي تم تركيبها في الجزء العلوي من الهجففلت ـ هنالك نوعان من العمل التجريبي ، أولا التجفيف بلون استخدام الصخور المخزنة

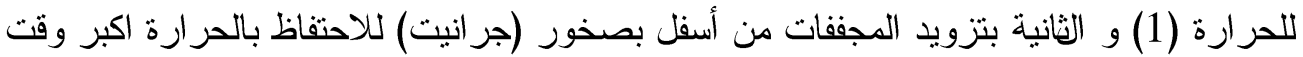
مكن (2) و ذلك لرفع كفاءة التجفيف. وكانت فترة التجفيف بدون صخور 51 ساعة و لكن كانت

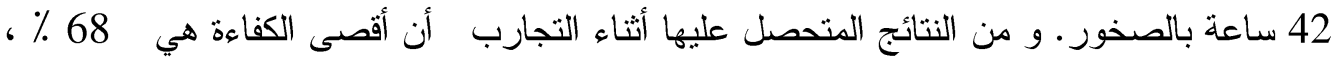

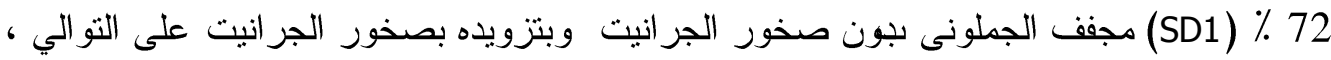

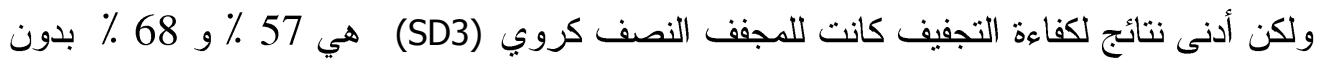

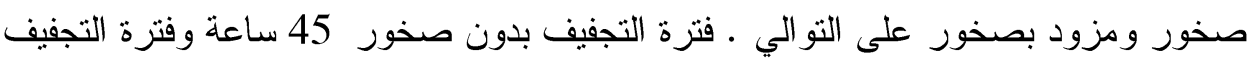
بالصخور 12 ساعة وأقصى محتوى الرطوبة نم إز الته أثناء التجارب كان للصوبة الجمالونية (SD1)

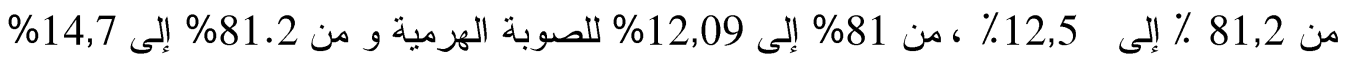

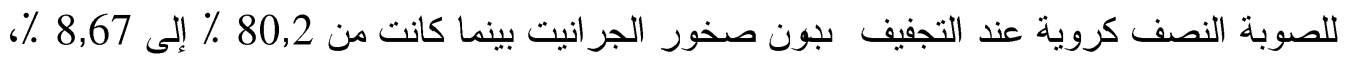

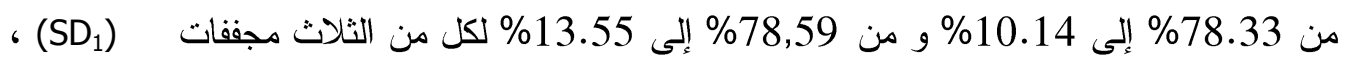
(SD $)$ ،لى التو الي أثناء تزويدها بصخور الجرانيت. مجموع الطاقة الثمسية الكلية خلال

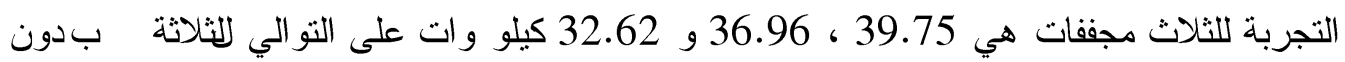

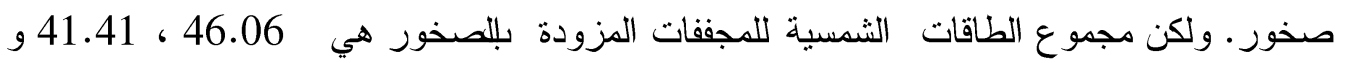
40.50 